\title{
Using the Fourier Transform in the Analysis of Vibration Load Tests of Heterogeneous Me- chanical Systems
}

\author{
Václav Bittner ${ }^{1}$, Richard Tuček ${ }^{2}$, Śárka Panská ${ }^{1}$, Martin Svoboda ${ }^{3}$, Karel Jelen ${ }^{1}$ \\ ${ }^{1}$ Faculty of Physical Education and Sport, Charles University, José Martího 31, Praha 6, Czech Republic and Faculty of \\ Science, Humanities and Education, Technical University of Liberec, Studentská 1402/2, Liberec, Czech Republic, E- \\ mail: vaclav.bittner@tul.cz, spanska@ftvs.cuni.cz., jelen@ftvs.cuni.cz. \\ ${ }^{2}$ Faculty of Science, Humanities and Education, Technical University of Liberec, Studentská 1402/2, Liberec, Czech \\ Republic, E-mail: richard.tucek@tul.cz. \\ ${ }^{3}$ Faculty of Mechanical Engineering of Jan Evangelista Purkyně University in Ústí nad Labem, Na Okraji 1001, Czech \\ Republic, E-mail: martin.svoboda@ujep.cz.
}

The aim of this study was to find possibilities of using the Fourier transform in the analysis of vibration load tests of heterogeneous mechanical systems, especially those of a biological nature. The study applied the idea that the dispersion of a stationary stochastic signal depends on its power spectral density. We have verified that a sophisticated reduction in the spectral power of the ergodic signal may be used to filter it effectively. The proposed procedure is suitable for the detection and separation of harmonic artefacts. We have created an algorithm in the MATLAB environment and tested its functionality when analysing the vibration transfer within the human axial system.

Keywords: Signal Filtering, Vibration Analysis, Heterogeneous Systems, Fourier Transform

\section{Acknowledgement}

This project was supported by grants PROGRES Q41, GAUK 962314 and SVV 260466 for the year 2017.

\section{References}

[1] BITTNER, V., PANSKÁ, Š., JELEN, K. (2016). Software pro vyhodnocení vibrační analýzy heterogenních systémů [software]. Evidenční č́slo KAB/2016/SW5. Praha: Fakulta tělesné výchovy a sportu Univerzity Karlovy. Dostupný z: http://www.ftvs.cuni.cz/FTVS-887.html.

[2] HLAVÁČ, V., SEDLÁČEK, M. (2000). Zpracováni signálůa a obrazů. Praha: Vydavatelství ČVUT. ISBN 80-0102114-9.

[3] KONVIČKOVÁ, S., VALENTA, J. (2006). Biomechanika člověka - svalově kosterni systém 1. díl. Praha: ČVUT. ISBN 80-01-03424-0.

[4] LAMPTON, M. (1997). Damping-undamping strategies for the Levenberg-Marquardt nonlinear least-squares method. Computers in Physics. 11(1), 110-. DOI: 10.1063/1.168600. ISSN 08941866.

[5] MARŠÍK, F., DVOŘÁK, I. (1998). Biotermodynamika (2nd revised edition ed.). Praha.NOVAK, J. (1996). Sample paper in book. In: Proceedings of xxx (D. Nový, (Ed.)), pp. 21 - 25. DEF Publisher, New York.

[6] MARŠÍK, F., ZEMAN, J., JELEN, K. (2010). Analysis of transmission of vibration trough the spine, measured by TVS method. Prague: Faculty of Physical Education and Sport, Department of Anatomy and Biomechanics.

[7] PANSKÁ, Š., PÍGLOVÁ, T., ZEMAN, J., MARŠÍK, F., LOPOT, F., \& JELEN, K. (2016). Evaluation of rheological parameters of the axial system using the transfer vibration through spine (TVS) method. Neuroendocrinology Letters, 37(4): 101-107.

[8] BLATNICKÝ, M., DIŽO, J., BLATNICKÁ, M.: Side Plate Strength Analysis of the Mechanism for Vehicle Axle Scale Calibration. In: Manufacturing Technology, Vol. 17, no. 2 (2017) pp 147-151, ISSN: 1213-2489

[9] SVOBODA, M., SOUKUP, J., JELEN, K., KUBOVÝ, P.: Effect of Impact on Human Head, In: Manufacturing Technology, Vol. 15, No. 2 (2015) pp 226-231, ISSN: 1213-2489

[10]ŠŤASTNIAK, P.: Freight Long Wagon Dynamic Analysis in S-Curve by Means of Comuter Simulation, In: Manufacturing Technology, Vol. 15, No. 5 (2015) pp 930-935, ISSN: 1213-2489

[11]MAREK, M., NOVÁK, M., RYTINA, T., DURAKBASA, M., N.: Process and Equipment Improvement for Nickel Brush Plating Application, In: Manufacturing Technology, Vol. 17, No. 4 (2017) pp 503-507, ISSN: 1213-2489 